\title{
Dubinsky, Karen et al. New World coming: the sixties and the shaping of global consciousness
}

Sílvio Marcus de Souza Correa*

Toronto: Between the Lines, 2009. 515p.

New World coming reúne mais de quarenta artigos apresentados durante um encontro internacional em junho de 2007, em Kingston (Canadá). Naquela ocasião, centenas de especialistas, estudantes e (ex-)militantes de vários países debateram sobre a década de 1960 e seus desdobramentos. Os artigos coligidos pelos editores para este livro representam amostra significativa de vários temas tratados durante quatro dias de verão na Queen's University.

Apesar dos diferentes temas e enfoques, a formação de uma consciência global perpassa todos os artigos. Questões como raça, gênero, sexualidade, nacionalidade, classe, religião, imperialismo, colonialismo, sexismo e capitalismo foram tratadas a partir de diversos lugares; porém, como afirmam os editores de New World coming, "every locality has a global history".

O quadro temporal das análises poderia dispensar maiores comentários sobre a sua relação com uma nova consciência global. No entanto, os próprios editores chamam atenção para a arbitrariedade ou fluidez de marcos, pois certas análises das tendências da década de 1960 podem ter a Guerra da Argélia (1954) ou a Conferência de Bandung (1955) por ponto de partida.

Ao levar em conta certos movimentos de resistência e protesto em várias localidades do globo, os editores de New World coming apresentam um conjunto de contribuições sobre as mudanças culturais, sociais e políticas da década de 1960 com base em suas particularidades históricas. Também logram enfoques inovadores com grupos de atores até então pouco conhecidos como, por exemplo, mulheres em Havana, jovens em Dacar, exilados caribenhos em Montreal ou trabalhadores porto-riquenhos em Nova York. O Ocidente deixa, portanto, de ser o epicentro de um mundo em transformação.

A primeira parte do livro (Nation-Descolonization-Liberation) explora as

\footnotetext{
* Doutor em sociologia pela Westfälische Wilhelms-Universität Münster (Alemanha); estágio de pós-doutorado, Institut National de la Recherche Scientifique (INRS), do Québec (Canadá). Depto. de História. Centro de Filosofia e Ciências Humanas - UFSC. Cidade Universitária. 88040-900 Florianópolis - SC - Brasil. silviocorrea@cfh.ufsc.br
} 
implicações do nacional para vários movimentos de libertação. Movimentos de descolonização na África e de redemocratização na América Latina não foram, todavia, o eixo temático dos 12 artigos que compõem a primeira sessão do livro. Movimentos de protesto e de resistência no Canadá, nos Estados Unidos, na Alemanha, na Itália e na Holanda são apresentados como elos de uma mesma cadeia, ou seja, de uma solidariedade internacional emergente na década de 1960. Estranheza causa a ausência de um artigo sobre a "revolução tranquila" no Québec. Ainda mais quando o assunto é nação, descolonização e libertação nos anos 60.

A segunda parte do livro (Cultural Citizenship) é composta por 12 artigos que enfatizam a circulação de ideias e valores em um mundo globalizado, ou melhor, em esfera cultural transnacional. São contribuições sobre novas subjetividades que se expressam por meio de produtos culturais, como filmes, músicas, peças teatrais e pôsteres, que circulam por vários espaços diferentes e que conectam pessoas através do mundo porque elas compartilham um novo imaginário social. Mas não se trata da cidadania dos habitantes da aldeia global de Marshall McLuhan. A maioria desses cidadãos se encontra em lugares desfavorecidos como um gueto em Chicago ou uma favela em São Paulo. Festivais de arte, manifestações da cultura popular e movimentos de contracultura foram tratados por vários especialistas, tendo por objetos de estudo a representação revolucionária no cinema cubano, o teatro de trabalhadores rurais na Suécia, os refritos da música pop internacional e sua importância para jovens mexicanos, o sentido de resistência da música soul na Tanzânia, o Primeiro Festival Mundial de Arte Negra, em Dacar (1966), a arte dos pôsteres de protestos etc.

Na terceira parte do livro (Mobilizing Bodies), dez artigos tratam da complexa politização do corpo durante aquela década. Destaque para a segunda onda do movimento feminista e seus desdobramentos. É nessa sessão do livro que aparece o único artigo sobre algo que se passou no Brasil à época. A organização dos primeiros grupos de conscientização de mulheres é o tema do artigo da historiadora Joana Maria Pedro (UFSC), que demonstra como outras professoras universitárias, com base em suas experiências nos Estados Unidos nos anos 60, introduziram em São Paulo e no Rio de Janeiro o modelo de consciousness-raising group. Esses primeiros grupos de conscientização foram organizados no início da década de 1970 e teriam uma função de rizoma, no sentido que Felix Guattari empresta ao termo. A conexão entre a segunda onda do feminismo em nível internacional e o que se organiza em termos de grupos de conscientização no Brasil nas décadas de 1970 e 1980 acusa um 
movimento de libertação que não deixa de ter suas implicações com a redemocratização da sociedade brasileira. Nesta terceira sessão do livro, o movimento feminista em Cuba, o radicalismo do feminismo nos Estados Unidos, o pacifismo e a consciência ecológica no Canadá e alhures são tratados de forma crítica. Injustificável é a falta de um artigo sobre a mobilização do corpo homossexual nessa década.

A quarta parte do livro (Lasting Legacies) enfoca alguns movimentos políticos e paisagens culturais forjadas durante a década de 1960. Ao tratar de algumas questões como a democracia participativa, os autores dos oito artigos que compõem esta última sessão fazem um tipo de balanço dos anos $60 \mathrm{com}$ base na identificação de alguns de seus desdobramentos nas décadas seguintes. Por epílogo, tem-se uma avaliação das possibilidades e problemáticas do 'Terceiro Mundo'. Algumas alternativas de cenário(s) futuro(s) são esboçadas, num louvável esforço intelectual para superar qualquer teoria de modernização, mas que mais parece um trabalho de Sísifo. Interessante é a atualização da alcunha de Albert Sauvy, inspirada no famoso panfleto do abade Sieyès, Qu'est-ce que le Tiers État? (1789). Ao almejar seu reconhecimento, o Terceiro Mundo transformaria seu potencial revolucionário em ato. Seriam essas experiências relatadas e analisadas em New World coming os indicadores de uma consciência global que, ancorada na solidariedade internacional e no reconhecimento da liberdade e da alteridade, emerge de um passado recente e serve de orientação para a construção de um novo mundo.

A proposta eclética de New World coming trata da década de 1960 e de seus desdobramentos com base em certos grupos em seus espaços da vida cotidiana. São trajetórias por geografias que implicam uma história sem centro, porém em conexão num mundo cada vez mais globalizado.

New World coming logra um mosaico da formação de uma consciência global a partir da década de 1960. Nesse sentido, a panóplia de movimentos de resistência sugere um grande movimento libertário, mesmo com seus descompassos e suas particularidades. Apesar do ecletismo e a descentralização da história proposta pelo livro, tem-se a impressão de que uma interpretação teleológica de história emerge do conjunto dos textos, como se um fim imaginado (de liberdade) fosse o ponto de partida em direção à década de 1960, período grávido de movimentos sociais, culturais e políticos que baliza(ra)m os caminhos atuais rumo ao reconhecimento da(s) liberdade(s). Enfim, um passado recente parece ter sido analisado com base num futuro próximo.

As evidências do legado dos anos 60 apontariam, então, para variações desse movimento global de libertação: os exemplos do movimento feminista 
em Cuba, no Brasil ou na Palestina, do pacifista de mulheres norte-americanas, do antirracista de jovens africanos ou afro-americanos, do ecológico de ambientalistas de países setentrionais, do democrático de exilados latinoamericanos seriam como vários afluentes desaguando no oceano da liberdade.

A leitura instigante das dezenas de artigos de New World coming não deixa de ser tentadora na medida em que nos dá a impressão de provarmos de um futuro que se antecipa, talvez com pressa, como se o que podemos ter amanhã já foi esboçado ontem. O risco de uma racionalidade a posteriori está presente em todas as partes do livro; mas as evidências de uma consciência global diante das injustiças do mundo contemporâneo foram tratadas com acuidade pelos articulistas. Resta saber até que ponto certa nostalgia da década de 1960 tolhe as análises e sínteses elaboradas pelos editores e coautores do livro.

Resenha recebida em outubro de 2009. Aprovada em dezembro de 2009. 